\title{
ENERGY
}

In The 21st Century

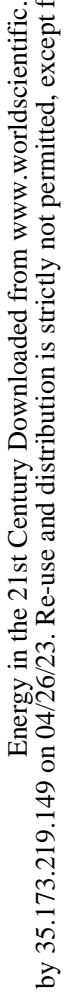


This page is intentionally left blank 


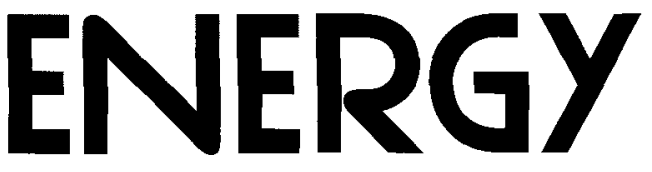

In The 21st Century

\section{JOHN R FANCHI}

Colorado School of Mines, USA 


\section{Published by}

World Scientific Publishing Co. Pte. Ltd.

5 Toh Tuck Link, Singapore 596224

USA office: 27 Warren Street, Suite 401-402, Hackensack, NJ 07601

UK office: 57 Shelton Street, Covent Garden, London WC2H 9HE

\section{British Library Cataloguing-in-Publication Data}

A catalogue record for this book is available from the British Library.

\section{ENERGY IN THE 21ST CENTURY}

Copyright $@ 2005$ by World Scientific Publishing Co. Pte. Ltd.

All rights reserved. This book, or parts thereof, may not be reproduced in any form or by any means, electronic or mechanical, including photocopying, recording or any information storage and retrieval system now known or to be invented, without written permission from the Publisher.

For photocopying of material in this volume, please pay a copying fee through the Copyright Clearance Center, Inc., 222 Rosewood Drive, Danvers, MA 01923, USA. In this case permission to photocopy is not required from the publisher.

ISBN 981-256-185-4

ISBN 981-256-195-1 (pbk)

Editor: Tjan Kwang Wei

Printed in Singapore. 


\section{This book is dedicated to those who support a sustainable energy future.}


This page is intentionally left blank 


\section{PREFACE}

My interest in energy began in the 1970's when I obtained degrees in physics from the Universities of Denver (B.S.), Mississippi (M.S.), and Houston (Ph.D.). I did some work in geothermal storage of solar energy as a post-doc in 1978 , and then spent many years in the energy industry helping develop oil and gas reservoirs. I became a full time academic in 1998 when I joined the faculty of the Colorado School of Mines as a professor of petroleum engineering.

In the transition from industry to academia, I wanted to find out how long a college graduate today could expect to continue a career in the extraction of fossil fuels. After studying several forecasts of energy production, I was convinced that fossil fuels would continue to be an important part of the energy mix while other energy sources would increase in importance. To help prepare students to function as energy professionals, I developed an energy course at the Colorado School of Mines and published the textbook Energy: Technology and Directions for the Future (Elsevier - Academic Press, Boston, 2004).

I realized as I was developing the energy course that much of the material in the textbook is suitable for a general audience. This book, Energy in the $21^{\text {st }}$ Century, is a nontechnical version of Energy: Technology and Directions for the Future. Energy in the $21^{\text {st }}$ Century was written to 
give the concerned citizen enough information about energy to make informed decisions. Readers who would like more detailed information or a more complete list of references should consult the textbook Energy: Technology and Directions for the Future.

I want to thank my students and guest speakers for their comments during the preparation of my energy course. Tony Fanchi helped prepare many of the figures in the book, and Kathy Fanchi was instrumental in the preparation and production of the book. Even though there are many more topics that could be discussed, the material in Energy in the $21^{\text {st }}$ Century should expose you to a broad range of energy types and help you develop an appreciation of the role that each energy type may play in the future.

John R. Fanchi

January 2005 


\section{CONTENTS}

Preface vii

A Brief History of Energy Consumption 1

Energy Options - Fossil Energy 24

Energy Options - Nuclear Energy $\quad 49$

Energy Options - Solar Energy $\quad 72$

Energy Options - Wind and Water 92

Energy Options - Biomass and Synfuels $\quad 118$

Hydrogen - An Energy Carrier 133

Electricity Generation and Distribution 148

Energy, Economics and the Environment 171

$\begin{array}{ll}\text { Energy Forecasts } & 197\end{array}$

Figure Credits $\quad 224$

References $\quad 227$

Index 234 